
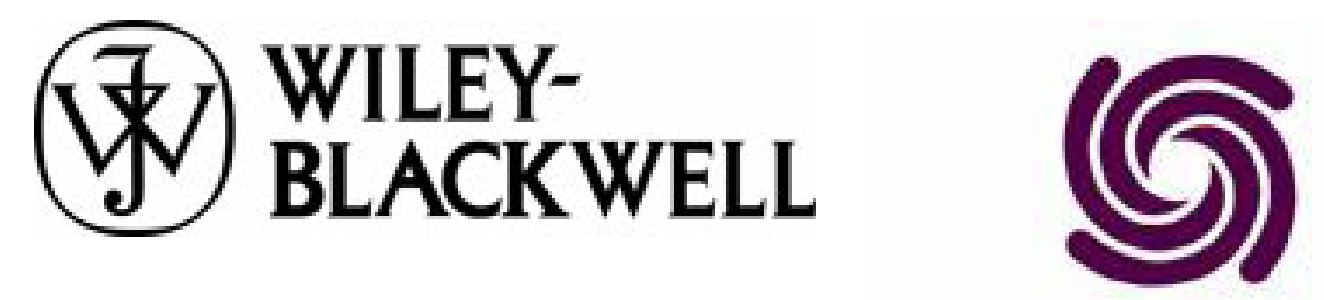

$\mathrm{A} \cdot \mathrm{M} \cdot \mathrm{E} \cdot \mathrm{R} \cdot \mathrm{I} \cdot \mathrm{C} \cdot \mathrm{A} \cdot \mathrm{N}$

ANTHROPOLOGICAL

A S S O C I A T I O N

The Hexis of Interpretation: Islam and the Body in the Egyptian Popular School Author(s): Gregory Starrett

Source: American Ethnologist, Vol. 22, No. 4 (Nov., 1995), pp. 953-969

Published by: Blackwell Publishing on behalf of the American Anthropological Association

Stable URL: http://www.jstor.org/stable/646394

Accessed: 20/09/2011 17:23

Your use of the JSTOR archive indicates your acceptance of the Terms \& Conditions of Use, available at http://www.jstor.org/page/info/about/policies/terms.jsp

JSTOR is a not-for-profit service that helps scholars, researchers, and students discover, use, and build upon a wide range of content in a trusted digital archive. We use information technology and tools to increase productivity and facilitate new forms of scholarship. For more information about JSTOR, please contact support@ jstor.org. 


\title{
the hexis of interpretation: Islam and the body in the Egyptian popular school
}

\author{
GREGORY STARRETT_University of North Carolina at Charlotte
}

The Christian traveler cannot look upon the religious rites of a strange people with idle curiosity; he will desire to penetrate their meaning, and the secret of their power. And yet the mere traveler will see only the surface of things; and it must be left to the philosophical student and the intelligent resident to explore the interior. [Thompson 1856:288]

In a 1989 review of the anthropological literature on the Arab world, Lila Abu-Lughod wrote that one of the more promising theoretical insights to emerge from research in the region was Pierre Bourdieu's notion of "body hexis," which, she explained, "suggests ways individuals come to live as natural, through their very body movements, the basic principles of an 'ideology.' " Specifically, she suggests applying the notion to "the organization of space in Muslim societies or the meaning of prayer and pilgrimage" (1989:296). In this article I will address Abu-Lughod's suggestion by looking at some ways in which body hexis has already been applied to Islamic ritual. In so doing, I will make two arguments. First, anthropological analyses of hexis that stress unconscious and ineffable meanings are of limited utility when dealing with Islamic ritual. For Muslims, who usually have some access to literate institutions, ritual hexis is always explicit to some degree. Second, bodily habit is inherently ambiguous, so that hexis is always subject to multiple interpretations. More significant than the implicit meanings of bodily hexis, then, are its public mediation and uses.

According to Bourdieu,

Bodily hexis is political mythology realized, em-bodied, turned into a permanent disposition, a durable manner of standing, speaking, and thereby of feeling and thinking. ... Principles em-bodied in th is way are placed beyond the grasp of consciousness, and hence cannot be touched by voluntary, deliberate transformation, cannot even be made explicit; nothing seems more ineffable, more incommunicable, more inimitable, and, therefore, more precious, than the values given body, made body by the transubstantiation achieved by the hidden persuasion of an implicit pedagogy, capable of instilling a whole cosmology, an ethic, a metaphysic, a political philosophy, through injunctions as insignificant as

"stand up straight" or "don't hold your knife in your left hand." [1977:93-94, emphasis in original]

Practical advice, standards of etiquette, styles of dress, manners of eating, and the very postures and expressions learned by mute observation are expressions of the habitus that both holds the individual within social networks of dominance and subordination and publicly marks his position. This complex "is transmitted in practice, in its practical state, without attaining the level of discourse" (1977:87), and the long process through which a child imitates and masters

This article examines how travelers, colonial officials, and educators have treated prayer and other body rituals in Egyptian popular schools. Once the object of colonial critiques of indigenous pedagogy, body ritual has now become the focus of a functionalist discourse that reads bodily postures and movements as natural manifestations of social, ideological, and cosmological structures. Starting from Bourdieu's notion of hexis, the literal embodiment of ideology, the article examines how Egyptians-and anthropologists_extract meaning from ritual behavior. [Egypt, Islam, education, ritual, colonial ideology, the body]

American Ethnologist 22(4):953-969. Copyright @ 1995, American Anthropological Association. 
these practical schemata is a "structural apprenticeship which leads to the em-bodying of the structures of the world" (1977:89).

"Hexis" " "habit" in classical Greek) appears particularly salient to the study of Islamic ritual life, which centers on the public performance of activities such as prostration, ablution, circumambulation, and fasting. But such rituals have long been subject to explicit interpretation by both Muslims and non-Muslims, who have attributed various inherent meanings to their performance.' Since the concept of hexis was developed originally to illuminate the meaning of bodily disposition in social systems in which such explicit, formal interpretation is absent (Bourdieu 1977:87), its application to the Muslim world becomes complicated. The changing ideological projects of both local and foreign elites often make ritual hexis a central feature of public and official cosmological constructions. As Bowen (1989:615) has shown for Indonesia, salat, the Muslim ritual of prayer, "cannot be 'decoded' semantically because it is not designed according to a single symbolic or iconic code. In particular times and places Muslims have construed the salat as conveying iconic or semantic meanings, but as part of particular spiritual, social and political discourses."

Thus, rather than conceiving of hexis primarily as a wordless, unconscious, and practical transmission of bodily habit, we might instead read "the embodiment of ideology in habit" as a set of processes through which individuals and groups consciously ascribe meaning to-or learn to perceive meaning in-bodily disposition, and to establish, maintain, and contest publicly its political valence. This is the broader context with in which a narrow reading of hexis as habitus-formation - "com[ing] to live as natural ... the basic principles of an 'ideology' " -must be understood. The relevant questions precisely concern the relationship between hexis and public discourse about hexis.

Toward that end we will examine two cases of the attribution of meaning to bodily hexis. Beginning with the writings of European travelers, colonial administrators, and indigenous educators, we will look at the way Victorians used the Egyptian body as a mnemonic device to express the ideology of European racial and cultural superiority. Latching onto the image of repetitive physical motion in performances such as Qur'an recitation in popular schools, prayer, and Sufi "dervish" dances, Europeans contrasted the Egyptian body-in-motion with an idealized body-at-rest, which they believed characterized their own, more "spiritual" approach to the world of the sacred. Reading into this contrast a number of negative assumptions regarding Egyptian mentality, spirituality, and social potential, European writers used the Egyptian body as a summarizing symbol (Ortner 1973) of cultural difference. Interestingly, the same processes operate today in the Egyptian public schools. In the second part of the article I analyze contemporary religious studies textbooks, children's literature, and discussions of the body in Egyptian classrooms, in order to show how the nation's educational establishment currently uses the dispositions of the Muslim body as symbols of cultural advancement, progress, and social order. This reversal is less a conscious reaction against the negative colonial readings of bodily hexis than it is a result of the inherent ambiguity of bodily disposition and the political flexibility of its interpretation. In the conclusion I will suggest that a Bourdieu-inspired reading of hexis partially reproduces Victorian understandings of the differences between primitive and civilized psychology, and thus requires some alteration.

\section{"see-sawing backwards and forwards the whole time"}

Would a scholar at the age of forty be able to sit for sixteen hours on end at his work-table if he had not, as a child, compulsorily, through mechanical coercion, acquired the appropriate psycho-physical habits? [Gramsci 1971:37]

We will begin by looking at the way European travelers in the 19th century interpreted certain ritual practices in Egyptian popular schools. In the 1830s, as the Egyptian Viceroy Muhammad 
Ali pressed ahead with his grand modernization schemes-introducing large-scale cash cropping, building railroads and factories, and establishing a European-style army - the number of European residents and travelers in Egypt began a dramatic increase. Often included in their rounds of the country's antiquarian marvels and modern curiosities was a stop at one of the many thousands of indigenous Qur'anic schools, or kuttabs (Arabic plural katatib), institutions that seldom failed to impress visitors with their exotic and troubling atmosphere.

Two things distinguished kuttabs from the schools Europeans knew at home: the Qur'an as the single subject of instruction and the physical arrangements for its communication. Here is how James Augustus St. John described an Alexandrian school of the 1830s:

In the appearance of the Medressy [Arabic madrasa, school] there was nothing remarkable, except that, instead of being seated on forms ranged regularly in the centre of the apartment, the boys were all squatted cross-legged upon a mat, with the pedagogue in the midst of them. In Egypt, Nubia, and, I believe, generally in Mohammedan countries, boys are taught to write upon a smooth thin tablet painted white, about the size of an ordinary ciphering-slate, with a handle at one end. From this the characters are easily effaced by washing. While studying, or rather learning to repeat, their lessons, each boy declaims his portion of the Koran aloud at the same time, rocking his body to and fro, in order, according to their theory, to assist the memory; and as every one seems desirous of drowning the voices of his companions, the din produced by so many shrill discordant notes reminds one of the "labourers of Babel." [1845:31 $32]^{2}$

The lack of furniture and the children's occasional involvement in economic pursuits, such as plaiting straw mats for sale, tended to upset foreigners whose understanding of schooling required a specific interior architecture, trained and disinterested professionals, and the full, uninterrupted attention of all parties. Visitors deprecated the unkempt appearance of kuttabs and, interpreting their physical organization as the result mainly of poverty, appealed for their provision with symbols of modern learning such as textbooks and blackboards.

Even more common is the special mention foreign accounts reserve for the rhythmic rocking behavior of student and teacher in the kuttab (a motion similar to that of Orthodox Jews while davening). ${ }^{3}$ In 1840 John Bowring told his readers that in Qena "the mode of instruction is the same as is adopted throughout the Ottoman empire. While the lesson is giving [sic], the master's head is in a state of perpetual vibration backwards and forwards, in which he is imitated by all the children" (1840:136). A decade later in Alexandria, Florence Nightingale wrote of the children "learning the Koran (see-sawing backwards and forwards the whole time)" (Nightingale 1987:26); at the end of the century in al-Mahalla al-Kubra, Basil Worsfold said that education "consisted, so far as the children were concerned, in the recital of passages from the Kuran, accompanied by a more or less energetic swaying of their bodies from the hips backwards and forwards" (1899:54). And Alfred Milner, the caustic Under-Secretary for Finance in Egypt during the early years of the British Occupation, turned the practice into a reverse metaphor for the learning process itself:

$[T]$ o sit on the ground swinging your body backwards and forwards, and continually repeating, in a monotonous chant, a quantity of matter which you are taught to regard with religious reverence, but never taught to understand, is, if anything, an anti-educational process. If the object of true education be intellectual gymnastic, if it be to exercise and render supple the joints of the mind, then this system is its very opposite, for it tends to stiffen them. It is not calculated to enlighten, but to obfuscate. [1 892:366]

On the heels of St. John's allusion to the regressive primal confusion of Babel, Milner's polemic highlights the ethnocentric Victorian perception that kuttab instruction violated reasonable standards of instruction in general and specifically those of religious and moral instruction. That the rocking motion had an important function-according to Egyptians, aiding the memorization and rhythmic cantillation of the Qur'an-mattered not at all. The kuttab's exotic arrangement and the constant, disconcerting physical motion of its tenants made it appear sensual, primitive, and antirational.

The visceral distaste with which the British greeted the schoolchild's rocking found its intellectual charter in contemporary theories of "primitive" religion, which by the end of the 
19th century had begun to turn away from the lofty intellectualist preoccupations of Spencer and Tylor and toward the investigation of the relative contribution of physiological versus mental processes in religious development. A whole body of literature, exemplified by Freud's later (1950[1912]) claim of the mental identity of children and savages, collapsed phylogeny onto ontogeny in treating the relationship between thought and action among the "lower orders," which included the working classes, nonwhites, women, children, and the mentally ill. Action was thought to precede language as a means of communication both historically (in theories of gesture as the origin of language) and developmentally. "In childhood," wrote Dudley Kidd,

before the higher inhibitions and controls have been established, there is a strong tendency for an idea to express itself in action. To put it in scientific language, an idea has an intrinsic motor-force-a fact that lies at the root of the imitative faculty. [1906:4]

As for the child, so it was for the "savage," among whom nonverbal religious displays like dance were customary and "stereotyped movements from which no individual dare depart," (Hambly 1926:17, 158) following the dictates of traditional tribal symbolism. Music itself was a spontaneous expression of "primitive" philosophy and emotion that savages were unable to express in words.

Therefore, for Europeans, if primitive religions had a significant emotional component, then higher religions were self-evidently systems of pure thought, like philosophy itself. Robert Ranulph Marett, who succeeded Tylor at Oxford, summarized this view in a famous proposition: "Savage religion is something not so much thought out as danced out; that, in other words, it develops under conditions, psychological and social, which favour emotional and motor processes, whereas ideation remains relatively in abeyance" (1914:xxxi).

On this classification of religious phenomena, not only the Egyptian schoolchild's physical rocking during lessons but even the ritual prostrations during Muslim worship itself appeared to the Victorian mind to be relatively backward, like the unreasoning dance of the savage. The Reverend Dr. Stephen Olin, president of Wesleyan University, toured Egypt and the Levant at the end of the 1850s, and, while admiring grudgingly the public nature of Islamic prayer for the devotion it revealed, read it primarily as "ostentatious hypocrisy ... destructive of the religion of the heart" and opposed to the "growth of internal piety" (1860:105-106). Emphasizing its repetitive nature, ${ }^{4}$ he reduced Muslim worship to a clever psychological trick. First came the call to prayer, whose "effect is thrilling and solemn in a high degree, and the circumstances admirably adapted to promote devotional feeling" (1860:103). ${ }^{5}$ Then came formal prayers, which

consist almost entirely in endless repetitions of a form which exalts the impostor as the true prophet of God, and thus effectually dishonours and rejects the Savior. "There is one God, and Mohammed is his prophet," is an epitome of the creed and worship of the Mussulman, which is heard everywhere with infinite and most tiresome iteration. Prayer seems to be thought acceptable in proportion to the number of times it gives utterance to this fundamental dogma. It is the burden of the call from the minarets, as well as of the devotions within the mosques; and the peasants and sailors, in their prayers, say almost noth ing else. No method could be devised better calculated to fix a deep impression upon the minds and hearts of the people. Mohammed discovered in this, as in many other usages and dogmas which belong to his system, a deep insight into the laws of the human mind. [1860:104]

Repetition spoiled devotional rites by making them altogether mechanical. The ablution before prayer, in the words of another midcentury traveler,

a ceremony altogether beautiful in its conception, and touchingly appropriate in its religious sentiments, is marred by its mechanical execution. The same is true of the attitudes of prayer. These are assumed with a mechanical uniformity quite foreign to a true devotion. [Thompson 1856:296]

The repetition of verbal formulae such as "It will be as God wills," "accompanied ... by almost none of the virtues of true piety," was an offensive encouragement to fatalism, "an argument that seems to produce in their minds willing submission," productive of paralysis and indolence on top of that generated by "the relaxing effects of the climate" (Olin 1860:107, 
emphasis in original). In the Victorian mind both the theological and the societal errors of the Egyptians could be derived from a fundamental mistake in the way they ordered their ritual life.

Back in the schoolroom, the repetitive and ritualized appearance of instruction and its reliance on the memorization of a linguistically obscure tex $t^{6}$ discredited the kuttab as a true educational institution in the same way that the automatic appearance of prayer disqualified it as true religion. Bourdieu's French precursors were no less derisive of Egyptian schoolroom behavior than were the British or Americans, although they chose to emphasize its psychological and class rather than its pedagogical implications. Octave Sachot, who toured Egyptian schools on behalf of the French Academy in the late 1860s, emphasized the rocking movement's lasting influence on students by reporting: "This sort of invariable sing-song, produced in a loud voice and accompanied by a rocking back and forth of the body, soon develops into a tic preserved in adulthood by most natives of the lower classes" (1868:4).

And Charles Pellissier, in his 1849 Rapport sur l'instruction publique en Egypte, charged that

The methods of instruction in the kuttab contribute from an early age to the degradation of the population. After their admission to the school nearly all the children lose the primitive vivacity, the intelligent animation of their countenances. Everyone knows that packed in an often too-small room, squatting all day long, they repeat all together in loud voices the verses taught to them by the master. The monotonous noise of these incessant cries and the oscillating movement that they impart to their bodies as they stammer the words without comprehension, soon produces among them a kind of intoxication resembling that of dervishes during certain religious festivals. [as cited in Salama 1939:300]

\section{"morbid and unwholesome deviations"}

Pellessier's comparison of students and dervishes goes beyond the Methodist Reverend Olin's conviction that repetitive ritual was theologically and behaviorally stultifying, to imply that it was related to positively noxious mental states. In contrast to the average traveler's relatively mild bemusement at the "quiet devotion, to which Moslems consider the pendulum action peculiarly conducive," (Steevens 1898:53) the spectacular performances of either "Whirling" or "Howling" Dervishes illustrated to Europeans "the cruelties of superstition and fanaticism" (Thompson 1856:288, emphasis in original), in which "wild and warlike" melodies and "degrading superstitions" convulsed their victims in "sickly and degenerate fancies" and rites that were "morbid and unwholesome deviations from the sage maxims of the great Prophet" (Rudolph 1884:234-235). Upset by a Dervish performance he attended in Cairo in the early 1880s, Crown Prince Rudolph of Austria declared:

Looking on makes one dizzy, and European blood runs cold at such sights. This height of fanaticism is appalling. Without moving an iota, in the same attitude these people turn with incredible rapidity. Their features are convulsed, the eyes turn out; the thin hands, and pallid cheeks set in their short beards, cut in Turkish fashion, betray all the painful signs of nerves disordered by depraved religious feelings. [Rudolph 1884:234-235]

The devotees seemed so far removed from higher mental functions that the "spasmodic energy" with which one collapsed dervish repeatedly gasped "Allah! Allah!" led Bayard Taylor to "suspect ... it was produced by the involuntary action of his larynx, and that he could not have stopped, even had he been so minded" (1860:56). Trying to penetrate more sympathetically the meaning of such performances, a member of the entourage of the Prince and Princess of Wales explained, "There is supposed by the savans to be some astronomical truth typified in the dance-the motions of the sun and planets"; but he then concluded sarcastically that "the dervishes did not look at all philosophical, and they certainly were not indifferent to terrestrial matters in the way of backsheesh" (Russell 1869:135). ${ }^{7}$

In all these cases the difference between matters philosophical and matters terrestrial was captured concisely in the image of the body in motion: the spinning dervish, the bowing prayer-maker, and the rocking schoolchild all had in common a physical engagement that 
appeared automatically to exclude mental activity. For Europeans, the dervish's wild rites banished both self-control and self-consciousness; the supplicant's repetitious devotions left no room for the development of true internal piety; and the pupil's oscillations precluded reflection and understanding.

For the Victorians, this last problem was a matter not merely of the structure but also of the content of instruction. Complaining this time of higher education at al-Azhar, the premier mosque-university of the Muslim world, the British emissary John Bowring wrote of "the most worthless character" of the curriculum as it stood in the 1830s. His differentiation between the religious concerns of Englishmen and Egyptians emphasizes the shortcomings Europeans saw in "Oriental" forms of religious instruction:

It turns principally upon the religious observances required by the Koran, and degenerates into extreme frivolity. Rarely is any lesson of morality given, and the passages of the Koran, which teach the cultivation of the virtues, are much less introduced and commented on than those which bear upon the ceremonials of the Mussulman faith. Inquiries as to the quantity of adulteration, which makes water improper for ablution - into the grammatical turn of the language of prayer-into the cases in which the obligations to fast may be modified-into the gestures in adoration most acceptable to Allah-into the comparative sanctity of different localities, and similar points - are the controversies which are deemed of the highest importance, and the settlement of which is supposed to confer a paramount reputation upon the Ulema [religious scholars]. [Bowring 1840:137]

If we read this passage from the perspective of Victorian religious sensibility, the contrast is one of ritual versus piety; concern for the outer (the symbolizing) is opposed to concern for the inner (the symbolized). Muslim religious values are represented as all surface and no depth: preoccupation with ceremonial, ablution, fasting, gesture, and grammar-all of the seemingly shallow manifestations of a primitive faith founded on formal reiteration rather than inner development.

But if we read the contrast from the perspective of pedagogical ideals, the contrast crystallizes around opposite ideals of the socialized body or, rather, an ideal of the socialized body and its opposite. Their bodily manifestations become the master symbols of difference between pedagogies, symbols through which Victorians read their ideological and political contrasts.

We can thus construct a table of contrasts and ask what different bodily attitudes mean. What ideologies do they articulate or embody? The Victorian version of this table expresses the contrasts by highlighting the exotic and disturbing aspects of the Oriental. It lists, on the Egyptian side, the meaningless oscillation and chaotic din of blind ritualism; on the European side, stillness, order, and morality. On the Egyptian side are dogma and taboo, the boundaries of purity and grammatical exactitude; on the European side, reason, the rejection of doctrinal minuteness, and the replacement of corporal notions of $\sin$ with the study of abstract ethical concepts. And so it goes on down the line: patriarchal traditionalism versus enlightened liberalism; memorization and repetition (mere appearance) versus comprehension and explanation (a transformation of inner state); intoxication and sensuality versus inward asceticism and silent attentiveness; the external marking of class versus the inward but conscious acceptance of relative position.

But there are of course other readings of these contrasts that view them from the opposite direction. The Reverend Olin admitted that Egyptians and Greeks both perceived Protestant disdain for ritual as a sign of religious indifference. More recently, Timothy Mitchell (1988) has compared the two pedagogies by exoticising the familiar European classroom rather than the Egyptian one. On the one side the Egyptian students collectively emulate the shaykh, swaying to and fro in the effort of mnemonic incorporation of the central cultural text, as the beginning of their participation in formal institutions of social reproduction. On the other side stands the Foucauldian architecture of doom in which the European student, stationary and disciplined, is molded spiritually into the rectilinear pattern laid down by the rows and columns of schoolroom benches, the disciplinary grid of supervision, evaluation, and recordkeeping 
(Mitchell 1988:69-92; see also Foucault 1977:210-223). On this view, the ideology embodied in the busy, disciplined subject is that of an emerging capitalist framework, and the process of training is, in Bourdieu's words, a "long dialectical process . . . through which . . . various fields provide themselves with agents equipped with the habitus to make them work" (Bourdieu 1990:67).

The juxtaposition of these two readings of difference is instructive for our consideration of body hexis because both construct political taxonomies from readings of the meaning of bodily motion. In Natural Symbols, her masterful treatment of the meaning of post-Enlightenment European antiritualism, Mary Douglas held that symbolisms of the body in different societies are associated with different constellations of status marking and social control. Furthermore,

If two symbolic systems are confronted, they begin to form, even by their opposition, a single whole. In this totality each half may be represented to the other by a single element which is made to jump out of context to perform this role. Other people select among our external symbols of allegiance those which offend or amuse them most. [1973:63]

Such an external symbol, in this case, is the kinetic shape of the body itself, the Egyptian body in motion versus the ideally still, disciplined body of the European. The Victorian traveler valorized the latter on the grounds that physical engagement was inappropriate to pedagogical and religious contexts and that its presence was a clear indicator of misdirection, ignorance, and pathology. Relative motion revealed relative status in the Victorian evolutionary schema. Europeans used the image of the rocking body to give substance to their racist presuppositions about primitive and modern psychology, and true versus false spirituality, and, by extension, to ideas about social evolution that helped construct the cultural hierarchy that justified the imperial mission.

For Mitchell and Foucault, on the other hand, physical stillness is both an index and an icon of the process of rendering the human subject docile through compulsory techniques of self-control that emerge from and facilitate transformations in technology and the division of labor (Foucault 1977:221). Relative motion reveals the creative operation of power. Where the Victorians read their own immobility as an expression of rationality, advancement, and piety, here it is read as an expression of entrapment, surveillance, and exploitation.

It is important to stress that the extraction of meaning from either of these bodies, moving or fixed, or from either of these systems of presumed hexis, is impossible outside specific relationships of objectification (Bourdieu 1977, 1990). "Meaning does not lie in the body" (Cowan 1990), and by themselves, of course, neither stillness nor motion means anything at all. Thinking about body hexis in terms of ideologies being em-bodied in gesture or stance is problematic because that inference of cosmology from behavior is potentially no more than the analyst's disguised projection of cosmology onto behavior, reading the latter as a direct manifestation of the former when it is in fact only an analytical trope. The European traveler and the contemporary scholar are involved in similar quests: to understand hexis as a physical manifestation of invisible but enduring (psychological, cosmological, or social) structures. As we will see later, the same applies to the praying Muslim himself. But bodily movement, like ritual action, does not contain meaning as an inherent quality, it is given meanings-often different and usually changing — by its various performers, by its various audiences, and by its anthropological spectators (Bowen 1989; Combs-Schilling 1989; Tapper and Tapper 1987; Turner 1967; Woodward 1989). Since the interpretation of bodily disposition is a social and ideological process that occurs on a number of different levels, and in which a number of different agents participate, there is no neutral or pure reading of the meaning of hexis, since all those who experience it and all those who read it are politically positioned. This will become clearer by following the course of religious instruction in Egypt since the 1890s. What we will see is that, in contemporary Egypt, the Victorian interpretations of the meaning of ablution and prayer have been exactly reversed. 


\section{"a token of advancement and civilization"}

By the end of the 19th century Lord Cromer, the British Consul-General in Cairo, had set in motion a plan slowly to systematize the country's several thousand scattered kuttabs, shaping them into a cheap, efficient, centralized system of elementary schooling, "so that the people may be rendered accessible to ideas other than those sanctioned by tradition" (1905:1165).

For 50 years, between 1898 and 1948, the Egyptian government operated two kinds of entry-level schools. In one, the elementary school, instruction was still largely religious. Most of these schools were formerly private kuttabs brought under the fiscal and then administrative control of the Ministry of Public Instruction. In addition to learning the Qur'an and the elements of reading, writing, and arithmetic, such schools were also to include a new kind of religion class outlining the fundamental features of Islamic history and practice.

In the second kind of school, the primary schools, a European-style curriculum was followed. Arithmetic, science, geography, physical education, drawing, Arabic, and foreign languages were emphasized. Graduates of primary schools, (as opposed to elementary schools) were allowed to continue their formal education if they possessed the means and possibly to earn the coveted school certificates that granted entry to the civil service. This clear class distinction was mirrored by a distinction in the form as well as the extent of religious instruction, matching very exactly the gulf the British perceived between proper and improper moral indoctrination. In the primary schools, according to an Egyptian professor of education, "religious education does figure, it is true, but now in the form of moral precepts, no more, no less.... The goal of Qur'an reading is entirely for linguistic purposes. The Ministry of Public Instruction recommends that the masters read without rocking, and in a very simple manner" (Salama 1939:316). The goal of teaching religion had been transformed to match the 19th-century European ideal of moral progress, as articulated by Bowring and others, and the stigma of the rocking motion is specifically targeted.

Following European models, Egyptian educators came to realize the potential political benefits of a form of religious instruction designed and delivered in order to further national political and social goals. In 1948 Neguib el-Hilali Pasha, the Egyptian Minister of Education, wrote:

Spiritual education and moral uplift are essential factors in education, and many of the calamities that beset the world at present are due to lack of spiritual education. But religious teaching should not be confined to the memorisation of religious precepts; it should rather take a practical trend. A service should be regularly held in school with an imam leading the boys in prayer. Sermons should be preached on simple subjects bearing on everyday life, within the comprehension of the young. The ulemas or students of religion should inculcate into the boys the habits of cleanliness and the elements of co-operation of which every Egyptian village is in great need. [1943:52 $]^{8}$

We have already been here, or somewhere very much like it. Note how strongly the passage recalls Bowring's description of al-Azhar, with bodies, purity, and acts of supplication all intertwined. But now the scholars, instead of lecturing to students about grammar and ritual purity, are supposed to instruct them in the elements of cooperation and hygiene. This returns us again to body hexis and to the way in which the Egyptian religious studies curriculum deals with issues of the body such as prayer and purity. What ideology do Egyptians see the physical act of prayer as embodying? What cosmology finds expression in modern Egyptian practices related to physical purity?

Currently, many Egyptian intellectuals and educators use Islamic principles to legitimize new technologies like in vitro fertilization, as well as corroborating Islamic concepts and practices with scientific and medical vocabulary. In April 1989 I ran across an example of this sort of linkage while observing a fifth grade classroom in a small private school in Muhandisin, one of the newer suburbs of Cairo. The religion teacher had her pupils open their textbooks and take turns reading aloud the following passage from a section of the text on "cleanliness": 
Cleanliness is next to Godliness [al-nidhafa min al-iman], and is one of the most important marks that distinguishes a Muslim person, because our Islamic religion calls for it, and impels the Muslim to it, even making cleanliness of the body and clothing one of the basic rules of prayer. . . . [Cleanliness] is a token of advancement and civilization, strongly bound to the progress of peoples, for advanced peoples are cleaner in their attire than others, and in their food and drink, and their streets. ... Perhaps the wudu' [ritual ablution before prayer] clarifies best the scope of Islam's interest in cleanliness, since it is part of prayer ... . it cleans man's body, and the modern physician has established that the wudu' a number of times a day brings health and keeps away skin diseases.... And among the manifestations of Islam's concern with cleanliness: that it calls on us to bathe for prayer on Fridays and on the two feast days. ... And the modern physician agrees with Islam in this, for doctors call on us to bathe at least once a week, guarding the body's cleanliness and freeing it from diseases. ... The conclusion is that whoever wants to maintain the teachings of his religion looks after cleanliness. And whoever wants people to love and respect him is neat and clean, for Islam is a religion of cleanliness, and therefore it is a religion of advancement and civilization. [Yunis et al. 1987:73-75]

This sort of textbook discourse is one of the ways Egyptians have attempted in the postcolonial period to create a "modern" version of Islam that can compete with European ideologies and media on their own terms (Starrett 1991). The first striking thing about this passage is its equation of the ritual purity of the wudu' with the physical purity of a secular bath, a hygienic practice within the domain of the physician rather than the theologian. The requirement of cleanliness in Islam rests on its presumed effect on health and well-being rather than its marking a separation between sacred and profane (see Douglas 1966:29, passim).

The second striking thing about the passage is its further linkage between cleanliness (e.g., of streets) and civilization, creating a hierarchy of peoples in which the Islamic community is historically the first and placing the sunna (traditionally accepted behavior) of the Prophet in the domain of the urban planner and the public health official. ${ }^{9}$ What Bowring denigrated in the 1840s as frivolous becomes for contemporary Egyptians a central sign of civilization.

The treatment of the wudu' elsewhere in primary school religion textbooks runs along the same path, consistently stressing its hygienic aspects. A note to the teacher in the first grade text, for example, advises that after the teacher has demonstrated the wudu' and watched her pupils perform it, she

should explain the benefits of the wudu' and the importance of its repetition to the maintenance of cleanliness, that this cleanliness induces health and vitality in the pupil, just as it produces pleasure in social intercourse with people, and not estrangement from them. [Y unis et al. 1988-89:44n].

In the second grade, pupils learn that "the wudu' is cleanliness," that it "protects you from illnesses," and that it "invigorates the body and protects it from diseases" (al-Naqa et al. 1988-89:28). In the fourth grade pupils are introduced to the istinja', the cleansing of the excretory regions of the body: "Islam ... calls on us always to bathe twice, or at least once a week. ... [T]he person must purify himself of remaining traces of urine or feces, and clean their outlets, until there is not an unpleasant smell, and one does not run the risk of diseases" (Yunis et al. 1987:35). Soap and water are praised, and in the set of exercises at the end of the section the seventh and eighth items on this subject read:

(7) Write the following statement in beautiful script: "The clean person washes his hands with soap and water when he emerges from the bathroom."

(8) Your little brother exits the bathroom and has not washed his hands - what do you say to him? [Yunis 1987:36]

This presentation of material as an activity or hypothetical situation is intended to raise it above the level of mere memorization, phrasing it in active, applied terms that children can not only remember, but remember to apply in everyday situations. In the contemporary school system morality and ethics, like hygiene, are treated as applied subjects, and, as in the case of cleanliness and civilization, unlikely connections often link the sacred with the function of the body or the social system. To give another example that returns us to the subject of order and discipline, according to the current second grade textbook the daily prayers not only "invigorate 

1988-89:29).

Let us examine this theme more closely. According to textbooks for the higher grades, the requirement of prayer is proof of the necessity for social order:

$[B]$ ecause in prayer there is rising and bowing and prostration, all actions that invigorate the body, and the Muslim devotes himself to work with zeal and energy, and increases production and spreads the good, and promotes [the progress of] the nation.... [P]rayer accustoms us to order, and the keeping of appointments, and the binding together of Muslims with cooperative ties and love and harmony.... [C]ollective prayer binds society with ties of brotherhood and equality, as it acquaints every Muslim with the condition of his brothers. [al-Dawwah 1986-87:158]

This idea is not restricted to government-issued publications. Private companies in Egypt now produce for young children a large volume of religious material that often picks up on the theme of order. One illustrated storybook, titled al-Sufuf al-Munadhdhama (Orderly Lines) compares two alternate realities on facing pages, illustrating the idea that "al-nidham min al-iman" ("orderliness proceeds from faith"). On one page, a clerk at a service window waits on patient men standing in a neat, quiet line, while on the facing page, an employee in a different office serves a pushy, unruly, and ill-mannered crowd whose own behavior undermines the clerk's ability to satisfy their requests. The first line proceeds in an orderly manner, each petitioner's papers being processed quickly and efficiently, while in the second scenario men butt into the front of the line, fights break out, and a wallet is stolen in the confusion of pushing and shouting. Soon the first employee has finished his work and can break for lunch, while no work has been completed in the second case.

In the final illustrations, the clerk in the first picture steps out of his office and begins to lecture the assembly on the facing page. "If only you knew the lesson that we learned from prayer," he says. "During collective prayer we must straighten the rows, just as in all our lives, we must have order, order." In the ensuing conversation he informs the crowd that God will not look favorably at prayer rows that are crooked, because Islam is a religion of order and discipline (al-islam din al-nidham wal-indibat). Order saves time and ensures fairness and the men of the crowd finally realize that God teaches us through everything. The straight rows of prayer teach us that order and discipline will help tranquility and satisfaction to prevail in all human endeavor (Yusif and 'Abduh 1988:14).

In the course of growing up Egyptian children mimic the physical skills of prayer at home from a very young age (parents tell me that it is not uncommon for two- or three-year-olds to begin imitating their parents at prayer). Educated parents claim that, until a child is over seven years of age, formal or explicit instruction goes against the advice of the Prophet. Childhood is supposed to be a time of play and exploration-under the direction of the mother-until the age of seven, when ideally the father should take charge of instructing the child explicitly in proper ritual behavior. ${ }^{10}$ Once at school the skills surrounding acts of public worship are taught formally, with attendant ideological elaboration, in the religion class. There they are displayed publicly in the form of recitation, response, and even on-demand demonstration of proper prayer positions, which are rehearsed (at least in pantomime fashion) from the first grade on.

\title{
the hexis of interpretation
}

\author{
Now, for Bourdieu,
}

[B]ody hexis speaks directly to the motor function, in the form of a pattern of postures that is both individual and systematic, being bound up with a whole system of objects, and charged with a host of special meanings and values. But ... schemes are able to pass directly from practice to practice without moving through discourse and consciousness. [1990:74; 1977:87] 
But the religious experience of Muslims is always defined in part by discourse, and we cannot, as Bourdieu appears to do, assume that "the structures, values, and attitudes of everyday life arise out of the ground" when in fact "practical activities evolve in relation to a worldview that is far more than a local construction" (Delaney 1991:20). ${ }^{11}$ The interpretation of the significance of prayer and of the lessons it is supposed to embody is an important aspect of the school's social and political role in Egyptian society. ${ }^{12}$ Egyptian children are taught in school that the straight lines of correct Muslim prayer "embody" the ideology of order and discipline. Significantly, this evaluation of the hexis of prayer reverses the Victorian reading of Muslim rituals (which marked them as primitive and stultifying), making them God's own sign of cultural advancement and order. In addition, it emphasizes the spatial layout of prayer as well as the individual's movements of prostration, thus fitting Muslim ritual practice squarely into an (explicitly positive) Foucauldian reading of disciplinary space. What is important in both these shifts is their illustration of the essential ambiguity in attributions of ideology to hexis. This is due both to contestations over the significance of specific habits (what does repetitive prostration mean?) and to the fact that in any ritual there are a number of features that can be made to signify. For example, Bowen (1989) has shown how local Indonesian communities, governments, and Islamic reform movements make specific aspects of prayer (e.g., formality and periodicity, its communicative functions, its public nature) express ideal models of society, political divisions, theological notions, and community structure.

Pointing out that the school operates to fix bodily disposition with explicit meaning is not just to say that the historical development of formal educational systems involves the articulation and explication by intellectuals of a formerly mute habitus, the creation of a hegemonic orthodoxy out of the ineffable background of doxa (the self-evident appearance of the natural and social world; from Bourdieu 1977:164, see also 1977:156,167-169). It can be argued that Islam presupposes a reflexivity in the social relations of intellectual production that automatically makes body hexis something other than a mute communication from body to body "without going through discourse or consciousness" (Bourdieu 1977:87). It is unlikely that "Islamic societies" have ever known a state of pure doxa, since the historical spread of Islamic institutions has usually involved social processes in which the fundamental ordering of the universe and the social world become the main items of contention, reordering, and dispute. There have always been struggles, large and small, in the legitimation of the Islamic worldview —or, rather, of one Islamic worldview versus another. Different local "orthodoxies" are regularly forged in reaction to the cultural assaults of the radio, the imported scholar, and the returning pilgrim or worker (Boddy 1989:52; Eickelman 1976:161-162; Lavie 1990:353).

Therefore, examining the extent to which interpretations of hexis are changed, manipulated, and made explicitly an object of contention is vital. The Egyptian child's learning that "Islam is a religion of order and discipline," through the example of the straight lines of prayer, is not only a matter of "coming to live as natural ... the basic principles of an 'ideology" " (Abu-Lughod 1989:296). In addition to learning to experience prayer as something orderly and disciplined, the child is learning more generally to interpret aspects of social reality as having meanings beyond those which they proclaim or manifest directly. It is this habit of interpretation-a practice in and of itself-that is transmitted through the implicit pedagogy of the contemporary school. This does not make the resulting ideological statements any less tendentious. But it naturalizes both the content of ideological statements and their creation, effectively democratizing the process of scriptural interpretation and encouraging the potential formation of counterhegemonies, of alternate structures of understanding and experience. The spread of interpretive authority to those outside the traditional class of Muslim scholars is in fact one of the sources of Egypt's politically volatile "Islamic Trend" (Goldberg 1991). While government textbooks say that collective prayer binds society with ties of brotherhood and equality and sympathy, some Islamic activist groups in Egypt counter that collective prayer is instead a sign 
of complicity with a modern society of unbelievers, and have restricted prayer to their homes (Kepel 1985:81).

Students learn to derive ideologies from the observation of practices and to read ideologies into gesture, motion, and ritual, just as Europeans mistakenly read into the schoolchild's rocking signs of mental stagnation and blind irrationality. The interpretation of the hidden import of bodily hexis thus becomes a kind of secular kabbalah, the tafsir (exegesis) of God's physical creation. Bodily disposition, as one aspect of that creation, is read as a signature of divine intention written in "the prose of the world" (Foucault 1970:26). In turn, different public interpretations of the meaning of specific practices (whether ritual, dance, or dress) not only influence conscious reflection on their abstract significance but influence individual experience of those practices (Cowan 1990). Learning to experience prayer as structure and discipline is very different from learning to experience it as a form of communication with God or as an expression of exclusivity (Bowen 1989). For Muslims, the em-bodying of ideology is in part an explicit, public, and discursive process, not merely an unconscious and practical one.

\section{conclusion}

As a final note, it is worth returning to the larger question of the use of body hexis as an analytical construct. I have claimed that various Muslim interpretations of their own bodily disposition, Victorian interpretations of that disposition, and contemporary academic readings of body hexis, while different in content, are formally similar. All invest body hexis with ideological contents that serve in part to validate the worldview of the observer and establish specific social and political relationships with the observed. The anthropological interpretation of hexis is no less a reading of "signatures" than that of the Victorian traveler (although we can hope it is both more sympathetic and more sophisticated.)

Bourdieu addresses the problem of objectification by claiming that anthropologists seem unable to "grant human dignity without granting what seems to be constitutive of that dignity" and that they "have never known how to rescue the people they were studying from the barbarism of pre-logic except by identifying them with the most prestigious of their colleagueslogicians or philosophers" (1990:37). ${ }^{13}$ But by focusing on practice to the exclusion of indigenous discourse about practice, he takes a giant leap backward to recapitulate the turn-of-the-century logic of Robert Marett. "In the time of Lévy-Bruhl," Bourdieu writes, "there would have been less amazement at the oddities of the 'primitive mentality' if it had been possible to conceive that the logic of magic ... might have some connection with the most ordinary experience of emotion or passion (anger, jealousy, hatred, etc.)" (1990:93). The religions and lives of those we study are not so much thought out as danced out; they are less a matter of cognition than of affect. There is a danger that an overemphasis on the unconscious, affective, and "embodied" aspects of ritual, or on the implicit communicative functions of disposition, might implicitly reproduce the Victorian dichotomy between "primitive" and "developed" forms of communication and infantilize and render mute the adult "Other." 14 While Bourdieu urges us to use our own understanding of the phenomenological experience of ritual while analyzing the rituals of others (1990:18), he fails fully to appreciate that we should also extend to others the "dignity" of abstraction and conscious agency (Jenkins 1992:87, 93). With respect to Islam this problem is particularly acute. The persistent claim that Islam is a religion of "orthopraxy," concerned with correct performance of ritual, rather than of orthodoxy, concern for correct belief, has been used in part by Western scholars to distance outer-directed Islam from inner-directed Christianity, the implication being again that "their" ritual is empty while "ours" has intellectual content.

To avoid this sort of danger we should pay particular attention to the relationship between body hexis and discourse, whether this occurs as formally articulated textbook explications of 
meaning, as the mobilization of verbal "calls to order" in the face of inappropriate bodily expression (Bourdieu 1984:380), or in some other fashion. If body hexis is a useful concept with respect to Islamic ritual, it is not so much as a mute, naturalized "em-bodiment" of ideology, but a matter of choosing bodily expressions of social boundaries (including the boundary of scientific objectification) and political goals. Any practice theory (Ortner 1984) that is to grant a space to agency and allow for the strategic use of cultural resources that Bourdieu himself stresses must move beyond a vague discourse of mute embodiment and toward one in which we can perceive in detail the ways in which the body is made symbolic, interpreted, and experienced as ideologically significant. It is in this direction-exploring the ways that the body is made an object of cultural and political contention - that we can most fruitfully extend the notion of body hexis in Islamic ritual.

notes

Acknowledgments. Research for this article was supported in part by the Egyptian Binational Fulbright Commission, the Stanford Center for International Studies, and the Mrs. Giles Whiting Foundation. Earlier versions were read before the Department of Anthropology, Harvard University, and the Department of Sociology, Anthropology, and Social Work at the University of North Carolina at Charlotte. I would like to thank those audiences, as well as $A E$ s editors and three anonymous reviewers, for their helpful comments. Special thanks go to Brian McVeigh for his insight and to Anna Laura Jones for her generous criticism as well as for her fine translations from the French.

1. Ironically, contemporary interpretations of ritual activity that focus on the embodiment of ideology seem not to have advanced much beyond Durkheim's positivist grounding of ritual in natural law. In Elementary Forms of the Religious Life, Durkheim wrote:

[I]t is an essential postulate of sociology that a human institution cannot rest upon an error and a lie, without which it could not exist. If it were not founded in the nature of things, it would have encountered in the facts a resistance over which it could never have triumphed. So when we commence the study of primitive religions, it is with the assurance that they hold to reality and express it. . . . [O]ne must know how to go underneath the symbol to the reality which it represents and which gives it its meaning. [1965(1915):14]

Currently, relations of dominance and subordination, gender inequalities or position in the world capitalist system simply replace social structure more narrowly defined as the realities to which myth and ritual allude (cf. Taussig 1980). The idea of body hexis as developed by Bourdieu appears to assume that hegemonic power/knowledge processes, expressing themselves through disposition, movement, and posture, can be read clearly through the body, because bodily states and activities are not merely analytical metaphors for structures of power and ideology but are quite literally manifestations of them. I would argue that this assumption is problematic because it can lead to the undervaluation of discursive practice, the avoidance of considerations of contradiction and change in the meaning of rituals, and the implicit return to an outdated Victorian evolutionary dichotomy between verbal and physical expression. The corollary of this is that the dispositions generated by the habitus may be bounded and context dependent rather than general and all-encompassing.

2. Some travelers agreed that the rocking motion was meant as a memory aid (e.g., Reynolds-Ball 1897:145), while others like Olin (1860:108) expressed the view that it was merely to "keep time to the chant." The latter was reported variously as "a curious monotone" (Reynolds-Ball 1897:145) or as being, in a report from Jaffa, "hilariously out of tune" (Hepworth-Dixon 1865:12). In an illustration of what Europeans counted as "fanaticism," Reynolds-Ball reported: "Some of the sects [at al-Azhar] are decidedly fanatical, and strangers will be well advised to abstain from any overt expression of amusement at the extraordinary spectacle of some thousands of students, of all ages, repeating verses of the Koran" $(1897: 145)$.

3. When I asked the rabbi of a California university Hillel organization what the meaning of this motion is for Jews, he said, "I haven't the faintest idea. In fact, I don't even know what the scriptural basis for it is. [Pause] But when people ask me, I tell them they should imagine being held, and rocked gently by God." He denied that it had anything to do with reinforcing memory of prayers or scriptural passages and pointed out that it is responsible for the high rate of eye problems among yeshiva students, who rock back and forth while reading from a stationary book, forcing the eyes constantly to focus and refocus on the page. In the end, he concluded in a practical sense that many of the prayers are so long and tedious that rocking back and forth gives one something to do with the time. I later told a friend who had done research with Orthodox Jews in Israel about the rabbi's story about being rocked by God, to which she replied, "Oh, God, he sounds just like a Christian preacher! No Orthodox Jew would say something like that!"

4. Olin writes: 
The prayer of the Mohammedan is accompanied by many prostrations ... passing through the same evolutions again and again.... There is great sameness in [the] simple songs [of the Egyptians], as well as in the Mohammedan prayers. They are chiefly made up of reiterations. [1860:106, 108]

5. Europeans and Americans remain strangely thrilled by the Muslim call to prayer. Delaney recalls her experience of rural Turkey as follows:

[W] hat one learns only by experience, is the way the amplified sound of the call punctuates daily rhythms and permeates the consciousness of believer and nonbeliever alike. The call is inescapable. That sound, repeated five times a day every day, every year, all of one's life, makes inroads on the brain. One begins to adjust one's own rhythms to the call and not the clock. . . This is bodily knowledge. [1990:516]

6. It should be remembered that the classical Arabic of the Qur'an-and its successor, "Modern Standard Arabic"-is not normally the spoken language of any Muslim country. Both 19th- and 20th-century educators in the Arab world have given attention to the problems encountered by students who enter school speaking local Arabic dialects but find instructional material written in what is essentially a foreign language with substantially different pronunciation, vocabulary, and grammar.

7. Tales of dervishes are so often rigidly horrified that it is a relief to come occasionally across a traveler with a sense of humor, albeit of a very special sort. The American Charles Leland described the aftermath of a whirling exhibition as follows:

Suddenly one of the dervishes, who had distinguished himself by his zeal, became mel bus, or possessed, and fell down. Had he been a Methodist or a Roman Catholic, a disciple of Madame Guyon or any of the five hundred writers whose names are given in Poiret's "De Mysticis," I should have said that he was inspired, or at least have shook my head gravely, and tenderly declared that it was wonderful and not to be lightly spoken of. It is thus that I feel and think even of Convulsionnaires. But as he was only a poor devil of a dervish, and a miserable heathen of a Mohammedan, it was plainly enough only an epileptic fit, and we regarded it accordingly. One lanky Yankee youth rushed up, and seizing him by the pulse produced his watch, and began timing him as if he had been a subject in the veterinary hospital suffering in the cause of science. The lanky youth talked very knowingly. When he had finished his share of the rites and exhibited sufficiently, a dervish rested the head of the possessed on his knee, and gradually chafed him again to consciousness. [1874:105]

Throughout his chapter on the dervishes, Leland sharpens the sardonic sense of th is passage by comparing the dervishes to Shakers, Holy Rollers, and other American sects known for their physical modes of worship.

8. Unable to separate Egyptian educational projects from European models, el-Hilali cited the Archbishop of Canterbury as an authority for the claim that religious subjects should form an important part of the school curriculum.

9. Concern with the health implications of ablution is relatively recent. A century ago, in his "Report on the Medical and Sanitary Administration of the Government of Egypt," H. R. Greene, Surgeon-Major and Sous-Directeur des Services Sanitaires d'Egypte (Deputy Director of Sanitary Services in Egypt), wrote:

Mosques in town and country are all provided with a basin for ablution, in which the water is seldom changed oftener than once in three months. Around this basin are placed a number of foul latrines communicating with a common drain, which, in most instances, runs into a tank or canal from where the drinking supply of the neighborhood is obtained. An examination of most of the principal mosque drains in Lower Egypt last year showed that 73 per cent. [sic] ended in the Nile or its branches and that 23 per cent. flowed into stagnant ponds of which the water was used for drinking purposes. In Egypt the Deity is invariably held to be the author of all disease, which should accordingly be submitted to with resignation; nor should any attempt be made by remedying defects to endeavor to controvert the will of the Almighty. [Greene 1885:78]

Sanitary reforms have been treated briefly by Mitchell (1988:64-68) and extensively by Kuhnke (1990).

10. Note that this claim fits Egyptian stereotypes of male and female roles into a patriarchal framework in which female : male :: immature : mature and also associates females with bodily expression and males with speech. The difficulty with taking this too far is that there is no good evidence that actual childrearing practices follow this pattern.

11. In his own work Bourdieu elides the mosque, making it an enclosure out of which the Kabyle have to step in order to be visible: the borders of his ethnography extend only to the doorstep where men take off their shoes to go and pray. This practical avoidance of formal Islamic institutions leads to inevitable contradictions in his Kabyle ethnography, in which he writes that "the structure of the day... integrates the five Moslem prayers very naturally" (1977:148) and then tells us a dozen pages later that the Kabyle men have moved the evening prayers forward to coincide with those at sunset (1977:160). Oddly, despite its focus on practice and process, Bourdieu's ethnography retains the oddly timeless quality of traditional anthropological accounts of an unchanging ethnographic present. This is particularly striking since his own fieldwork took place in the midst of the Algerian war for independence, in an area occupied by the liberation forces. Bourdieu never introduces us to the young men, stoned on hashish, with machine guns hidden under their cloaks (Harker et al. 1990:40-41).

12. It is perhaps significant that in retracing ground covered by Mauss's (1935) "Techniques of the Body," Bourdieu never cites his predecessor. For Mauss, unlike Bourdieu, habitus was largely a practiced and conscious acquisition. In Mauss's examples, Maori mothers drill their daughters in walking properly just as his own gymnastics teacher "taught me to run with my fists close to my chest: a movement completely 
contradictory to all running movements" (1973[1935]:73). "There is no technique and no transmission," he writes, "in the absence of tradition. This above all is what distinguishes man from the animals: the transmission of his techniques and very probably their oral transmission" (1973[1935]:75).

In Distinction (1984), his most developed substantive discussion of hexis to date, Bourdieu outlines the hierarchy of "class bodies" in France, noting that "the body is the most indisputable materialization of class taste" $^{\prime \prime}$ (1984:190), whose "fundamental principles of ... identity and unity . . . lie in the unconscious" (1984:384). Writing that food choice, manners of eating, use of cosmetics, and general "care" of the body express different relations to the social world and "function as social markers . . . in the system of distinctive signs ... homologous with the system of social positions" (1984:192), Bourdieu treats hexis as an expression of habitus that is actively read by self and others. The body, as "the only tangible manifestation of 'the person', is commonly perceived as the most natural expression of innermost nature" (1984:192). In his reading of contemporary France, Bourdieu sees the same principles we found in the Victorian reading of the rocking Egyptian schoolchild, from "the restraint and impassivity which signify elevation" (1984:177) to the notion that "the legitimate use of the body is spontaneously perceived as an index of moral uprightness, so that its opposite, a 'natural' body, is seen as an index of . . 'letting oneself go' " (1984:193). Bourdieu shows us the embarrassed "hypercorrection" of the petit bourgeois in the company of their betters and mentions charm schools where working-class girls "undergo a radical transformation in their way of walking, sitting, laughing, smiling, talking, dressing, making-up, etc." (1984:205-206), but he does not systematically address the relationship between hexis and ideology or discourse. We are told only that class bodies are policed by "calls to order ('Who does she think she is?' 'That's not for the likes of us') which reaffirm the principle of conformity - the only explicit norm of popular taste-and aim to encourage ... 'reasonable' choices" (1984:380).

In other words, hexis is socially activated through commentary, rather than being entirely outside the reach of words. Unmentioned, violations of class hexis remain a feeling, a disquiet, mere unfocused anxiety, until mobilized through a native objectification of practice, its strategic use for the maintenance of solidarity or the characterization of an "other." A clearer articulation of th is idea might be to say that political ideologies are not "em-bodied" in hexis; rather, bodily dispositions are "class-ified" and made to stand for difference. It is because of this that body hexis has not any one meaning, but only meaning as perceived by different audiences. Bourdieu recognizes this in his discussion of the values of virility among the French working classes, which are valorized by themselves but treated as roughness, vulgarity, and clumsiness by others.

13. This is a swipe at Paul Radin's Primitive Man as Philosopher.

14. In Distinction, for example, Bourdieu characterizes aesthetic choices as being "alien" to workingclass women (1984:379; see Jenkins 1992:148) and writes of "the extraordinary realism of the working classes" (1984:380-381) in terms reminiscent of Malinowski's suggestion that " $\mathrm{t}] \mathrm{he}$ road from the wilderness to the savage's belly and consequently to his mind is very short" (1948:44).

\section{references cited}

Abu-Lughod, Lila

1989 Zones of Theory in the Anthropology of the Arab World. Annual Review of Anthropology 18:267-304.

Boddy, Janice

1989 Wombs and Alien Spirits: Women, Men, and the Zar Cult in Northern Sudan. Madison: University of Wisconsin Press.

Bourdieu, Pierre

1977 Outline of a Theory of Practice. Cambridge: Cambridge University Press.

1984 Distinction: A Social Critique of the Judgement of Taste. Richard Nice, trans. Cambridge, MA: Harvard University Press.

1990 The Logic of Practice. Richard Nice, trans. Stanford, CA: Stanford University Press. Bowen, John

1989 Salat in Indonesia: The Social Meanings of an Islamic Ritual. Man (n.s.) 24:600-619.

Bowring, John

1840 Report on Egypt and Candia. London: House of Commons Sessional Papers, vol. 21. Combs-Schilling, M. Elaine

1989 Sacred Performances: Islam, Sexuality, and Sacrifice. New York: Columbia University Press.

Cowan, Jane $\mathrm{K}$.

1990 Dance and the Body Politic in Northern Greece. Princeton: Princeton University Press.

Cromer, Lord (Sir Evelyn Baring)

1905 Reports by His Majesty's Agent and Consul-General on the Finances, Administration, and Condition of Egypt and the Soudan. Sessional Papers, vol. 103. London: House of Commons. al-Dawwah, Mahmud al-Sayyid, Muhammad ${ }^{\mathrm{C}}$ Ali Sulayman, Mahmud Kamil al-Naqa, and ${ }^{\mathrm{C}}$ Abdal-Wahab Muhammad Mas ${ }^{\mathrm{c}}$ ud

1986-87 Al-Tarbiya al-Islamiyya. Al-Saff al-Sabi ${ }^{\mathrm{C}}$. (Islamic Education. The Seventh Grade.) Cairo: al-Jihaz al-Markazi lil-Kutub al-Jami ${ }^{\mathrm{C}}$ iyya wa al-Madrasiyya wa al-Wasa'il al-Ta ${ }^{\mathrm{C}}$ limiyya (The Central Agency for School and University Books and Instructional Media). 
$\rightarrow$ Delaney, Carol

1990 The Hajj: Sacred and Secular. American Ethnologist 17:513-530.

1991 The Seed and the Soil: Gender and Cosmology in a Turkish Village. Berkeley: University of California Press.

Douglas, Mary

1966 Purity and Danger. London: Routledge \& Kegan Paul.

1973 Natural Symbols. New York: Vintage.

Durkheim, Emile

1965[1915] Elementary Forms of the Religious Life. New York: Free Press.

Eickelman, Dale F.

1976 Moroccan Islam. Austin: University of Texas Press.

Foucault, Michel

1970 The Order of Things. New York: Vintage.

1977 Discipline and Punish. New York: Pantheon.

Freud, Sigmund

1950[1912] Totem and Taboo. New York: Norton.

$\rightarrow$ Goldberg, Ellis

1991 Smashing Idols and the State: The Protestant Ethic and Egyptian Sunni Radicalism. Comparative Studies in Society and History 33:3-35.

Gramsci, Antonio

1971 Selections from the Prison Notebooks of Antonio Gramsci. Quintin Hoare and Geoffrey Nowell Smith, trans. and eds. New York: International Publishers.

Greene, H. R.

1885 Report on the Medical and Sanitary Administration of the Government of Egypt. Enclosure in item No. 19 in Egypt No. 15 (1885), Reports on the State of Egypt and the Progress of Admin istrative Reforms. Sessional Papers, vol. 89 (1884-85). London: House of Commons.

Hambly, W. D.

1926 Tribal Dancing and Social Development. London: H. F. \& G. Witherby.

Harker, Richard, Cheleen Mahar, and Chris Wilkes, eds.

1990 An Introduction to the Work of Pierre Bourdieu: The Practice of Theory. New York: St. Martin's Press.

Hepworth-Dixon, William

1865 The Holy Land, Vol. 1. Leipzig: Bernhard Tauchnitz.

el-Hilali, Neguib

1943 Report on Educational Reform in Egypt. Cairo: Government Press, Boulaq.

Jenkins, Richard

1992 Pierre Bourdieu. Key Sociologists Series. London: Routledge.

Kepel, Gilles

1985 Muslim Extremism in Egypt: The Prophet and Pharaoh. Berkeley: University of California Press.

Kidd, Dudley

1906 Savage Childhood: A Study of Kafir Children. London: Adam and Charles Black.

Kuhnke, LaVerne

1990 Lives at Risk. Berkeley: University of California Press.

Lavie, Smadar

1990 The Poetics of Military Occupation. Berkeley: University of California Press.

Leland, Charles

1874 The Egyptian Sketch Book. New York: Hurd and Houghton.

Malinowski, Bronislaw

1948 Magic, Science, and Religion. New York: Doubleday.

Marett, Robert Ranulph

1914 The Threshold of Religion. London: n.p.

Mauss, Marcel

1973[1935] Techniques of the Body. Economy and Society 2:70-88.

Milner, Alfred

1892 England in Egypt. New York: Macmillan.

Mitchell, Timothy

1988 Colonising Egypt. Cambridge: Cambridge University Press

al-Naqa, Dr. Mahmud Kamil, Mahmud al-Sayyid al-Dawwah, Muhammad Mukhtar Amin Makram, and

Muhammad 'Ali Sulayman

1988-89 Al-Tarbiya al-Islamiyya. Al-Saff al-Thani. (Islamic Education. Second Grade.) Cairo: al-Jihaz al-Markazi lil-Kutub al-Jami iyya wa al-Madrasiyya wa al-Wasa'il al-Ta ${ }^{\mathrm{C}}$ limiyya (The Central Agency for School and University Books and Instructional Media).

Nightingale, Florence

1987 Letters from Egypt: A Journey on the Nile 1849-50. Anthony Sattin, ed. New York: Weidenfeld \& Nicholson.

Olin, Reverend Stephen D. D.

1860 Travels in Egypt, Arabia Petraea, and the Holy Land, Vol. I. New York: Harper \& Brothers. 
Ortner, Sherry

1973 On Key Symbols. American Anthropologist 75:1338-1346.

1984 Theory in Anthropology since the Sixties. Comparative Studies in Society and History 26:122-166.

Reynolds-Ball, Eustice A.

1897 The City of the Caliphs. Boston: Dana Estes.

Rudolph, Crown Prince of Austria.

1884 Travels in the East; Including a Visit to Egypt and the Holy Land. London: Richard Bentley and Son.

Russell, William Howard

1869 A Diary in the East, during the Tour of the Prince and Princess of Wales. London: George Routledge and Sons.

St. John, James $A$.

1845 Egypt and Nubia. London: Chapman and Hall.

Sachot, Octave

1868 Rapport adressé a Son Excellence Monsieur Victor Duruy, Ministre de I'Instruction Publique, sur L'état des sciences, des lettres et de l'instruction publique en Egypte dans la population indigéne et dans la population européenne. (Report to His Excellence Monsieur Victor Duruy, Minister of Public Instruction, Concerning the State of the Sciences, Arts, and Public Instruction in Egypt, among the Indigenous and European Populations.) Paris: n.p.

Salama, Ibrahim

1939 L'énseignement islamique en Egypte: son évolution, son influence sur les programmes modernes. (Islamic Education in Egypt: Its Evolution and Its Influence on Modern Programs.) Cairo: Imprimerie Nationale, Boulac.

Starrett, Gregory

1991 Our Children and Our Youth: Religious Education and Political Authority in Mubarak's Egypt. Ph.D. dissertation, Stanford University.

Steevens, G. W.

1898 Egypt in 1898. New York: Dodd, Mead.

Tapper, Nancy, and Richard Tapper

1987 The Birth of the Prophet: Ritual and Gender in Turkish Islam. Man (n.s.) 22:69-92.

Taussig, Michael

1980 The Devil and Commodity Fetish ism in South America. Chapel Hill: University of North Carolina Press.

Taylor, Bayard

1860 Journey to Central Africa; or, Life and Landscapes from Egypt to the Negro Kingdoms of the White Nile. 10 th ed. New York: G. P. Putnam.

Thompson, Joseph P.

1856 Photographic Views of Egypt, Past and Present. Boston: John P. Jewett.

Turner, Victor

1967 Symbols in Ndembu Ritual. The Forest of Symbols. Pp. 19-47. Ithaca, NY: Cornell University Press.

Woodward, Mark R.

1989 Islam in Java: Normative Piety and Mysticism in the Sultanate of Yogyakarta. Tucson: University of Arizona Press.

Worsfold, W. Basil

1899 The Redemption of Egypt. London: George Allen.

Yunis, Fathi ${ }^{\mathrm{C}}$ Ali, ${ }^{\mathrm{C}} \mathrm{Ali}{ }^{\mathrm{C}}$ Abdal-Maujud al-Qadi, ${ }^{\mathrm{C}}$ Abdal-Khalil Ahmad Hamad, and Salah ${ }^{\mathrm{C}}$ Abdal-Hafidh

Fayad

1987 Al-Tarbiya al-Islamiyya. Al-Saff al-Rabic (Islamic Education. Fourth Grade.) Cairo: al-Jihaz alMarkazi lil-Kutub al-Jami i iyya wa al-Madrasiyya wa al-Wasa'il al-Ta ${ }^{\mathrm{C}}$ limiyya (The Central Agency for School and University Books and Instructional Media).

1988-89 Al-Tarbiya al-Islamiyya. Al-Saff al-Awwal. (Islamic Education. First Grade.) Cairo: al-Jihaz al-Markazi lil-Kutub al-Jami'iyya wa al-Madrasiyya wa al-Wasa'il al-Ta' limiyya (The Central Agency for School and University Books and Instructional Media).

Yusif, ${ }^{\mathrm{C}}$ Abd al-Tuwab, and Dr. Yahya ${ }^{\mathrm{C}}$ Abduh

1988 Al-Sufuf al-Munadhdhama. (Orderly Lines.) Cairo: Safir.

submitted March 10, 1993

revised version submitted March 3, 1994

revised version submitted August 1, 1994

accepted September 22, 1994 